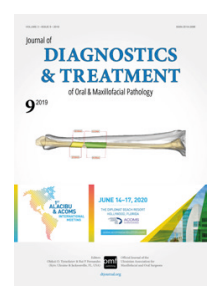

Editorial

\title{
Journals and PlumX Metrics
}

\author{
Oleksii 0. Tymofieieva, levgen I. Fesenkob, \\ \& João Luiz Gomes Carneiro Monteiro
}

Information technology is at the core of how you do your business and how your business model itself evolves.

-Satya Nadella

CEO, Microsoft

Plum Analytics (also known as PlumX) is an online tool which belongs to altmetrics (full term: alternative metrics) data providers and measures of hidden research impact based on online activity - such as saving of papers in Mendeley, downloads, social media sites (Facebook, Twitter), and blogs. ${ }^{1,2}$ PlumX history: founded in 2012 by Andrea Michalek and Mike Buschman, acquired by EBSCO Information Services in 2014, and final acquisition by Elsevier happened in 2017. ${ }^{3}$ PlumX was successfully integrated into Elsevier`s products, including Scopus, ScienceDirect, Pure, Mendeley, and SciVal. ${ }^{4}$ PlumX categories of metrics are: citations, usage, captures, mentions, and social media.

So, how PlumX works we can see on the example of Elsevier's gold open access journal focused on head and neck surgery - Otolaryngology Case Reports. ${ }^{6}$ The journal's official webpage contains PlumX link to the article of Barber et al. ${ }^{7}$ Article`s metrics

a Editor in Chief, DTJournal; Kyiv, Ukraine.

E-mail: tymofeev@gmail.com (Oleksii Tymofieiev)

${ }^{\mathrm{b}}$ Managing Editor, DTJournal, Kyiv, Ukraine.

E-mail: i.i.fesenko@dtjournal.org (levgen Fesenko)

${ }^{c}$ Web \& Social Media Editor, DTJournal, Recife, Pernambuco, Brazil and Boston, MA, USA.

E-mail: joaoluizgcm2@gmail.com (João Luiz Monteiro)

https://dx.doi.org/10.23999/j.dtomp.2019.9.1.

(c) 2019 OMF Publishing, LLC. This is an open access article under the CC

BY license (http://creativecommons.org/licenses/by-nc/4.0/). details included: usage - 13 (twelve abstract views and one link-out), captures -2 , and social media 1 (in Twitter). ${ }^{8}$ Category 'Usage' represents clicks, downloads, views, library holdings, and video plays. ${ }^{5}$ Category 'Captures' shows bookmarks, favorites, reference manager saves, and watchers. ${ }^{5}$ Category 'Social media' means likes, shares, and tweets.

So, it's an honor to editorial staff of DTJournal and OMF Publishing company to congratulate Elsevier with implementation of a powerful altmetrics tool which definitely helps individual researchers uncover the full impact of their work. ${ }^{1}$ Furthermore, researchers who know how their project is impacting the scientific community get inspired to do their best in future projects.

\section{REFERENCES}

1. Champieux R. PlumX. J Med Libr Assoc 2015;103:634. https://dx.doi.org/10.3163/1536-5050.103.1.019.

2. Priem J. Altmetrics. In: Cronin B, Sugimoto C. $\mathrm{R}$, editors. Beyond bibliometrics: harnessing the multidimensional indicators of scholarly impact. Cambridge, MA: MIT Press; 2014.

3. Carpenter TA. Plum goes orange - Elsevier acquires Plum Analytics [document on the internet]; February 02, 2017 [cited 2019 Sep 22]. Available from: https:// scholarlykitchen.sspnet.org/2017/02/02/plum-goesorange-elsevier-acquires-plum-analytics/.

4. Staff. Elsevier continues to expand journal analytics through acquisition [document on the internet]; February 03, 2017 [cited 2019 Sep 22]. Available from: https://campustechnology.com/articles/2017/02/03/ elsevier-continues-to-expand-journal-analyticsthrough-acquisition.aspx.

5. McCullough R. PlumX metrics API now available for Scopus subscribers [document on the internet]; July 02, 2019 [cited 2019 Sep 22]. Available from: https:// blog.scopus.com/topics/plumx-metrics.

6. Fesenko II. Gold open access journal focused on head and neck surgery: analysis of business model and level of article processing charges during the first 31 months of publishing. J Diagn Treat Oral Maxillofac Pathol 2019;3:202-12. https://dx.doi.org/10.23999/j. dtomp.2019.8.6.

7. Barber S, Kopach P, Genega E, Carroll T. Low grade spindle cell sarcoma of the true vocal folds. Otolaryngology Case Reports 2018;7:13-5. https:// dx.doi.org/10.1016/j.xocr.2017.11.006.

8. PlumX metrics: Low grade spindle cell sarcoma of the true vocal folds [document on the internet]; 2018 [cited 2019 Sep 22]. Available from: https://plu.mx/ plum/a/?doi=10.1016/j.xocr.2017.11.006. 